\title{
PEMBIDANGAN METROLOGI PADA LEMBAGA METROLOGI NASIONAL LUAR NEGERI
}

\author{
Jimmy Pusaka
}

\begin{abstract}
Institute for metrology at national level has an important role in improving product competitiveness from the quality assurance point of view. It is needed to propose good strategy to enable national metrology institute in Indonesia to have capability that meets national requirements on physical standards. Study on structure of national metrology institutes and the possibility of their standardisation is, therefore, important. This paper describes comparison results of the grouping of metrology on physics in various national metrology institutes in Asia-Pacific region, as inputs for the decision makers.
\end{abstract}

Keywords: metrology, metrology on physics

\section{PENDAHULUAN}

\subsection{Lembaga Metrologi Nasional}

Lembaga metrologi nasional adalah suatu institusi, atau unit kerja yang bertanggung jawab sebagai pengelola (custodian) standar ukur yang paling tinggi tingkat akurasinya di suatu negara. Pada umumnya negara maju telah memiliki lembaga metrologi nasional, sementara sebagian negara berkembang ada yang masih belum memilikinya dengan alasan tingginya biaya investasi dan perawatan peralatan standar, sementara hasilnya secara komersial tidak signifikan. Berdasarkan ini, maka peran pemerintah sangat besar dalam mengelola lembaga metrologi nasional di negara masingmasing.

Pentingnya peran lembaga metrologi nasional berdampak kuat pada kemajuan industri di negara tersebut. Hal ini disebabkan oleh terjaminnya standar ukur yang digunakan di industri-industri, melalui suatu skema pemeriksaan reguler yang bermuara pada standar nasional yakni standar dengan tingkat akurasi yang paling baik, yang dikelola oleh lembaga metrologi nasional di negara tersebut. Negara yang belum memiliki lembaga metrologi nasional sendiri, dapat mengacu pada standar nasional yang dimiliki oleh lembaga metrologi nasional negara lain sebagai referensi bagi standar industrinya.

\section{DASAR TEORI}

\subsection{Variasi Kepengelolaan Lembaga Metrologi Nasional}

Lembaga metrologi nasional pada umumnya merupakan organisasi yang dimiliki dan dioperasikan oleh pemerintah. Alasan di balik itu dapat bermacam-macam, antara lain unit ini adalah organisasi nirlaba, bertujuan untuk mengutamakan kepentingan nasional, atau membutuhkan dana yang sangat besar untuk pemeliharaan standar dan kegiatan lainnya. Bentuk kepengelolaannya dapat berbeda dari suatu negara ke negara lain tergantung pada situasi setempat, yang dapat menempatkannya pada posisi setingkat eselon satu, dua atau tiga.

Dalam uraian ini didiskusikan pembidangan disiplin metrologi, yang membahas struktur organisasi lembaga metrologi nasional. Dalam beberapa hal, pengelompokan dilakukan dengan memisahkan pengukuran fisis, pengukuran kimia, pengukuran radiasi, dan pengukuran lainnya. Namun keseragaman ini tidak selalu tampak dari suatu lembaga ke lembaga lainnya. Ketercampuran disiplin masih terlihat dengan berbagai alasan seperti penyederhanaan struktur karena lembaga terkait berukuran kecil; upaya penyatuan kelompok antara cabang dan ranting disiplin keilmuan; maupun penyatuan antara disiplin kemetrologian dan disiplin riset yang sebidang. Pemisahan yang tegas antar berbagai disiplin pengukuran memang tidak selalu mudah dilakukan, tetapi sangat membantu dalam penyusunan tanggung jawab, dan dalam pemberian layanan yang profesional serta berkualitas kepada pelanggan yang dapat berbentuk laboratorium terakreditasi maupun industri

\section{METODOLOGI}

\subsection{Rancangan Studi Banding Kepengelolaan Lembaga Metrologi Nasional}

Dalam penelitian ini dipelajari model-model kepengelolaan lembaga metrologi nasional di berbagai negara, untuk dijadikan bahan perbandingan agar dapat ditarik suatu kesimpulan mengenai bentuk yang paling tepat untuk diusulkan menjadi lembaga metrologi nasional di Indonesia. Lembaga metrologi nasional yang dipelajari adalah yang berkedudukan di Asia Tenggara, Asia Timur, dan Oceania. Pilihan Asia Tenggara adalah karena 
pertimbangan geografis, bahwa Indonesia sebagai negara anggota ASEAN memiliki iklim, keadaan geografis, kemajuan di sektor ekonomi, serta kebudayaan yang bermiripan satu dengan lainnya. Pilihan Asia Timur adalah karena negara-negara di kawasan ini merupakan representatif negara Asia yang maju. Sedangkan Oceania dibatasi hanya untuk Australia dan Selandia Baru saja, mengingat mereka adalah negara tetangga yang dipandang sebagai negara maju yang berorientasi ke barat. Sementara India disisipkan sebagai bahan perbandingan dengan status sebagai lembaga metrologi tertua di Asia Selatan.

Negara-negara yang berhasil diperoleh data lembaga metrologi nasionalnya dapat dilihat pada Tabel 1.

Tabel 1 Daftar Lembaga Metrologi Nasional Asia Tenggara, Asia Timur, dan Oceania

\begin{tabular}{|c|c|c|c|}
\hline No & Negara & Lembaga Metrologi Nasional & Tahun mulai beroperasi \\
\hline \multicolumn{4}{|c|}{1 Asia Tenggara } \\
\hline 1.1 & Malaysia & SIRIM Berhad & 1974 \\
\hline 1.2 & Philipina & $\begin{array}{l}\text { National Metrology Laboratory of the } \\
\text { Philippines (NMLPHIL) }\end{array}$ & 1987 \\
\hline 1.3 & Singapura & SPRING Singapore, National Metrology Centre & - \\
\hline 1.4 & Thailand & National Institute of Metrology (NIMT) & - \\
\hline 1.5 & Vietnam & Vietnam Metrology Institute (VMI) & 1962 \\
\hline \multicolumn{4}{|c|}{2 Asia Timur } \\
\hline 2.1 & China & National Institute of Metrology (NIM) & 1955 \\
\hline 2.2 & China & $\begin{array}{l}\text { National Research Centre for CRMs } \\
\text { (NRCCRM) }\end{array}$ & - \\
\hline 2.3 & Hongkong SAR & Standards and Calibration Laboratory (SCL) & - \\
\hline 2.4 & Japan & National Metrology Institute of Japan (NMIJ) & 1903 \\
\hline \multirow[t]{2}{*}{2.5} & Korea Selatan & $\begin{array}{l}\text { Korea Research Institute of Standards and } \\
\text { Science (KRISS) }\end{array}$ & 1975 \\
\hline & Korea Selatan & Korea Agency for Technology and Standards & \\
\hline 2.6 & Taiwan & $\begin{array}{l}\text { Industrial Technology Research Institute, } \\
\text { Centre for Measurement Standards (CMS/ITRI) }\end{array}$ & 1983 \\
\hline 2.7 & Taiwan & Institute of Nuclear Energy Research (INER) & - \\
\hline 2.8 & Taiwan & $\begin{array}{l}\text { National Standard Time and Frequency } \\
\text { Laboratory }(T L)\end{array}$ & 1969 \\
\hline \multicolumn{4}{|c|}{3 Asia Selatan } \\
\hline 3.1 & India & National Physical Laboratory (NPLI) & 1947 \\
\hline 3.2 & India & BARK & - \\
\hline \multicolumn{4}{|c|}{4 Oceania } \\
\hline 4.1 & Australia & National Metrology Institute (NMIA) & 1824 \\
\hline 4.2 & Australia & $\begin{array}{l}\text { Australian Radiation Protection and Nuclear } \\
\text { Safety Agency (ARPANSA) }\end{array}$ & - \\
\hline 4.3 & Selandia Baru & $\begin{array}{l}\text { Measurement Standard Laboratory of New } \\
\text { Zealand (MSL) }\end{array}$ & 1989 \\
\hline
\end{tabular}

\section{HASIL DAN PEMBAHASAN}

\subsection{Konstelasi Metrologi}

Dari sudut pandang konstelasinya, metrologi dapat dibagi ke dalam tiga kelompok yakni metrologi ilmiah, metrologi industri, dan metrologi 
legal. Ketiga kelompok ini memiliki karakteristik yang berbeda terutama pada bidang aplikasinya, sekali pun metrologi ilmiah dan metrologi industri mempunyai beberapa kesamaan teknis. Perbedaan di antara kedua yang disebut terakhir lebih pada tingkat akurasi yang dapat dicapai. Metrologi ilmiah pada umumnya memiliki tingkat akurasi yang tinggi sampai sangat tinggi. Bidang aplikasinya adalah pemeliharaan standar nasional, interlaboratory comparison standar nasional suatu negara terhadap standar nasional negara lain, menjaga ketertelusuran suatu standar nasional terhadap satuan SI-nya, dan mendiseminasikan suatu standar nasional kepada standar lain yang berada satu tingkat di bawahnya. Metode metrologi yang diterapkan menggunakan cara-cara yang paling baik yang dapat dipertanggungjawabkan secara ilmiah untuk menentukan kebenaran nilai ukur suatu benda metrologi.

Di sisi lain, metrologi industri memiliki segmen aplikasi dengan tujuan industri. Pada umumnya metode metrologi yang dipergunakan mempunyai nilai-nilai akurasi yang cukup untuk kepentingan pemakaian di industri seperti pengukuran bahan, inspeksi produk setengah jadi, inspeksi produk akhir, dan kalibrasi peralatan ukur (termasuk peralatan pengujian) di tingkat industri. Semua standar ukur yang dipergunakan sebagai acuan dalam proses kalibrasi bagi peralatan tingkat industri ini harus tertelusur ke standar yang lebih tinggi yang berada dalam lingkup metrologi ilmiah.

Sesuai dengan tujuan primernya, semua lembaga metrologi nasional didirikan untuk dapat memberi layanan metrologi ilmiah di negaranya masing-masing. Namun sesuai pula dengan kemampuan teknisnya, pada umumnya lembaga metrologi nasional juga memberi layanan metrologi industri.

\subsection{Pembidangan Metrologi}

Dalam kaitannya dengan pelayanan prima kemetrologian yang dibutuhkan dalam suatu negara, sebuah lembaga metrologi nasional harus berupaya untuk menyesuaikan perangkat sistem standar yang dimilikinya agar dapat memenuhi permintaan laboratorium kalibrasi daerah, industri dan pihak-pihak pemakai lainnya. Pada metrologi ilmiah dan metrologi industri, kebutuhan tersebut pada umumnya dapat dibagi ke dalam tiga golongan besar, yakni metrologi fisik, metrologi kimia, dan metrologi radiasi. Metrologi fisik dapat dikatakan sebagai kelompok metrologi yang paling tua karena sudah dikenal sejak 6.000 tahun yang lalu. Kelompok metrologi ini jugalah yang paling banyak dikuasai oleh lembaga metrologi nasional di berbagai belahan bumi. Secara garis besar pembidangan metrologi fisik berdasarkan disiplinnya dapat dilihat pada tabel di bawah pada kolom paling kiri.

Struktur pembidangan metrologi fisik di atas disusun berdasarkan hasil studi banding dari berbagai struktur organisasi lembaga metrologi nasional. Dari hasil studi banding itu juga terungkap bahwa tidak semua lembaga metrologi nasional memiliki secara lengkap perangkat metrologi fisik, dan tidak semua lembaga mengikuti struktur di atas. China memisahkan Electromagnetic Division dari RF \& Microwave Division, dan memiliki Quantum Division yang berdiri sendiri. Taiwan memisahkan Electromagnetic dari Electrical Division, dan memasukkan Optical Frequency Standard ke dalam Dimensional Division. Australia menaruh Hygrometry di bawah Mass and related quantities. India menaruh hampir semua disiplin dalam level yang sama dengan hanya dibagi ke dalam dua kelompok besar yakni Physico Mechanical dan Electrical \& Electronic Standards. Secara lebih lengkapnya, pembidangan metrologi fisik pada berbagai lembaga metrologi nasional dapat dilihat pada ikhtisar dalam tabel 2 berikut:

Tabel 2 Pembidangan Metrologi Fisik 


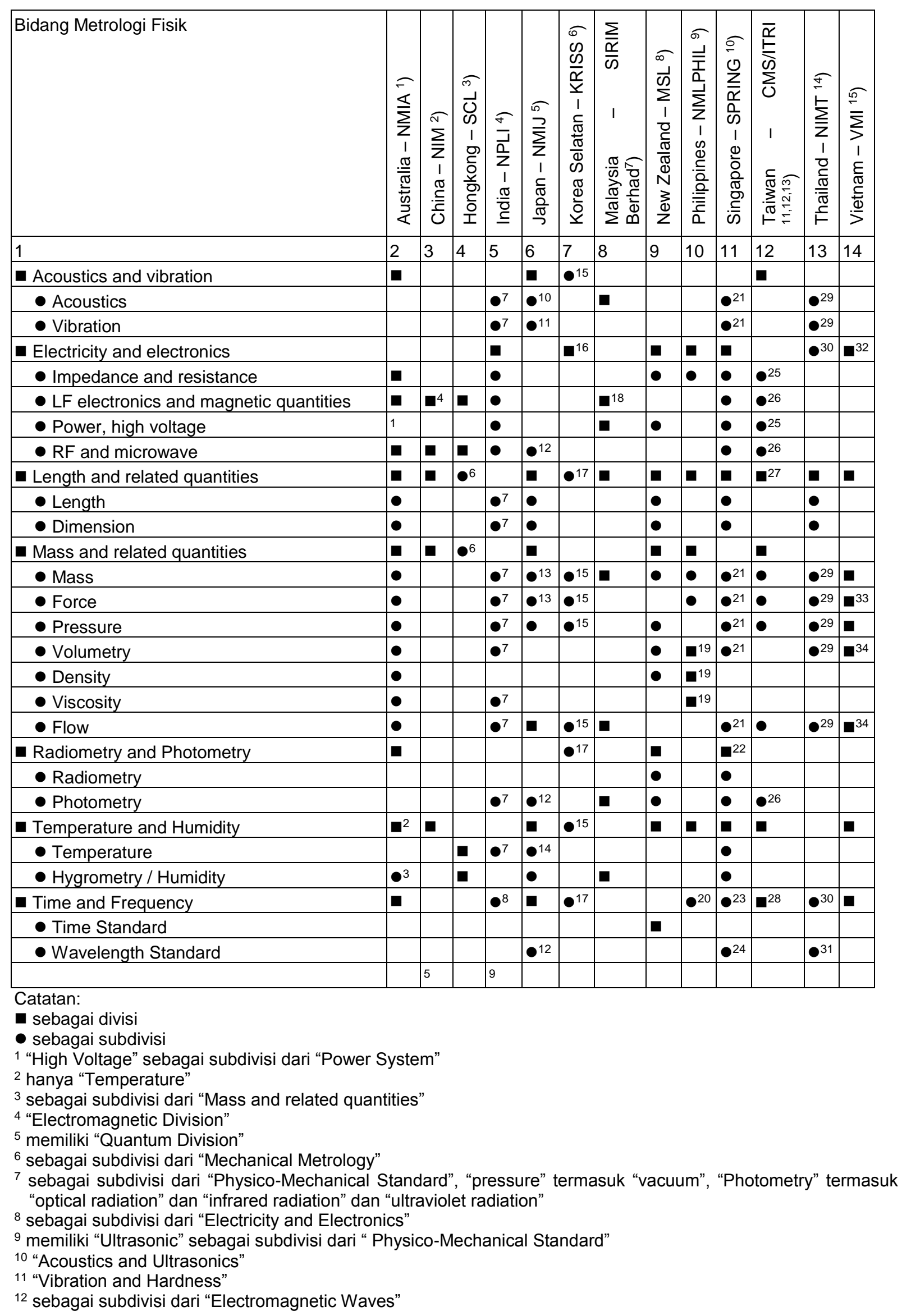


13 bergabung

14 Terpisah dalam tiga subdivisi "Thermometry", "Cryogenic Thermometry", dan "Radiation Thermometry"

15 sebagai subdivisi dari "Physical Metrology", "Mass" bergabung dengan "Force", "Pressure" diisi dengan "Vacuum Technology"

16 Divisi "Electromagnetic Metrology" dengan subdivisi "Electricity \& Magnetism", "Biomagnetism", "Electromagnetics", dan "Electronic Devices"

${ }^{17}$ sebagai subdivisi dari "Optical Metrology" dengan subdivisi tambahan "Optical Nanometrology"

18 terbagi menjadi dua divisi "DC \& Low Frequency Group", dan "Magnetic"

19 tergabung menjadi satu divisi

${ }^{20}$ sebagai subdivisi dari "Electrical"

${ }^{21}$ sebagai subdivisi dari "Mechanical" dengan subdivisi tambahan "Hardness"

22 dengan subdivisi tambahan "Spectroradiometry", "Spectrophotometry", dan "Colorimetry"

23 sebagai subdivisi dari "Electromagnetic"

${ }^{24}$ sebagai subdivisi dari "Dimensional"

${ }^{25}$ sebagai subdivisi dari "Electrical Division"

${ }^{26}$ sebagai subdivisi dari "Electromagnetic"

27 termasuk subdivisi "Optical Frequency Standard" dan "Geodetic Measurement"

28 dioperasikan oleh Chung Hwa Telecom Co, Ltd

${ }^{29}$ sebagai subdivisi "Mechanical Metrology", "Acoustics" bergabung dengan "Vibration", "Volumetry" bergabung dengan "Flow", "Force" mencakup "Torque", "Pressure" mencakup "Vacuum"

${ }^{30}$ sebagai subdivisi dari "Electrical Metrology"

31 sebagai subdivisi dari "Dimension Metrology"

32 "Electricity" dan "Electromagnetics" merupakan dua divisi yang terpisah

33 mencakup "Hardness"

34 "Volume" bergabung dengan "Flow"

\subsection{Pembidangan Metrologi di Indonesia}

Puslit KIM-LIPI sebagai lembaga metrologi nasional utama di Indonesia memiliki dan mengelola sejumlah standar fisik yang paling banyak diperlukan di Indonesia.

Lembaga metrologi nasional di Indonesia ini memiliki enam subdivisi (istilah resmi yang digunakan adalah subbidang) yakni Panjang, Massa, Kelistrikan, Temperatur, Radio \& Fotometri, dan Akustik \& Getaran, di mana dipelihara tujuh standar satuan ukuran fisik yang berfungsi untuk mengoperasikan metrologi ilmiah dan metrologi industri, dengan lingkup sebagai berikut:

a. Iodine-stabilised $\mathrm{He}-\mathrm{Ne}$ laser, $633 \mathrm{~nm}$

b. Electronic standard cell group, $1,028 \mathrm{~V}$ dan $10 \mathrm{~V}$

c. Standard resistor group, $1 \square$ dan $10 \mathrm{k} \square$

d. $\mathrm{H}_{2} \mathrm{O}$ TP $0,01^{\circ} \mathrm{C}$, Sn FP $231,928^{\circ} \mathrm{C}$, Zn FP $419,527^{\circ} \mathrm{C}$, BB Cu FP $1084,62^{\circ} \mathrm{C}$, Ga FP, Al FP

e. Group of luminous intensity lamps, 241244,6-245,8-282-287-289,5 cd

f. GPS time keeping system, $1 \sim 10 \mathrm{~ns}$

g. Ensemble of Cs frequency standards, $1 \mathrm{MHz}$, $5 \mathrm{MHz}$, dan $10 \mathrm{MHz}$

Sementara standar satuan ukuran fisik untuk besaran massa dipegang oleh Direktorat Metrologi (di bawah Departemen Perdagangan) dalam bentuk Pt-Ir kg standard (K-46).

Membandingkan dengan perkembangan pembidangan metrologi di luar negeri, tampaklah bahwa lembaga metrologi nasional di Indonesia hanya menempatkan diri sebagai "Divisi", dengan enam sub-divisi. Sementara lembaga metrologi nasional lain pada umumnya memiliki beberapa divisi, sehingga fokus yang rinci bagi setiap standar dapat lebih terperhatikan karena tanggung jawab pembinaannya disebar di bawah subdivisi masing-masing dengan dikoordinasi oleh divisinya.

\section{KESIMPULAN DAN SARAN}

- Dilihat dari fungsinya dalam memelihara standar nasional untuk satuan ukuran termasuk menjaga nilai ukurnya agar tetap tertelusur ke satuan SI, dan mendiseminasikan nilai ukur standar nasional tersebut ke standar-standar lain di seluruh wilayah suatu negara, lembaga metrologi nasional adalah pihak yang secara keteknikan paling bertanggung jawab dalam penentuan tingkat daya saing di negara tempat ia berada.

- Dalam bidang metrologi fisik, Electrical and electronics, Length and related quantities, dan Mass and related quantities merupakan disiplin yang paling banyak dilayani oleh lembaga metrologi nasional di wilayah Asia Tenggara, Asia Timur, Asia Selatan, dan Oceania. Semua lembaga yang disurvey memiliki sebagian atau seluruh kemampuan disiplin tersebut. Sementara yang paling sedikit adalah Acoustics and vibration, dan Radiometry and photometry. Hanya 60\% dari lembaga yang disurvey memiliki sebagian atau seluruh kemampuan dalam 
bidang ini. Kondisi yang sangat berdekatan juga berlaku bagi lembaga metrologi nasional di lingkungan ASEAN. Radiometry and photometry menempati posisi terakhir di ASEAN dengan hanya $40 \%$ lembaga yang menyediakan pelayanan dalam bidang ini.

- Hasil studi ini dapat dilanjutkan ke arah upaya standardisasi lembaga metrologi nasional untuk mencapai persyaratan minimumnya.

- Kondisi di Indonesia saat ini, lembaga metrologi nasional kita hanya menangani besaran fisik saja, dan hanya menempatkan diri sebagai sebuah divisi, sementara lembaga metrologi nasional luar negeri pada umumnya memiliki beberapa divisi sehingga pemeliharaan standar nasional dapat lebih terperhatikan.

\section{DAFTAR PUSTAKA}

1. www.measurement.gov.au/

2. en.nim.ac.cn/
3. www.info.gov.hk/itc/scl/eng/scl.shtml

4. www.nplindia.org/npl/index.htm

5. www.nmij.jp/newenglish/index.html

6. www.kriss.re.kr/

7. www.sirim.my/

8. www.irl.cri.nz/msl/

9. mis.dost.gov.ph/itdi/services $/ \mathrm{nml} / \mathrm{nml}$.htm

10. www.spring.gov.sg/portal/products/metrology /services/metrology.html

11. www.itri.org.tw/eng/index.jsp

12. www.cms.itri.org.tw/eng/news/index.php

13. www.stdtime.gov.tw/english/e-home.htm

14. www.nimt.or.th/nimt_en/index.asp

15. www.vmi.gov.vn/

\section{BIODATA}

Jimmy Pusaka, dilahirkan pada tanggal 2 Oktober 1953, menyelesaikan pendidikan S2 dari University of Zalford Inggris 1987. Penulis sekarang bekerja di Puslit KIM LIPI. 